\title{
純 $\mathrm{Al}$ およ゙ $\mathrm{Al}-0.2 \% \mathrm{Cu}$ 合金鋳塊における 等軸晶の生成について
}

鈴木 章** 中村実人** 圾本敏 $\mathrm{IE}^{* *}$

Akira Suzuki, Jitsuhito Nakamura and Toshimasa Sakamoto : Formation of the Equiaxed Grains in Pure Aluminum and Al-0.2\% Cu Alloy Ingots. The origin of the equiaxed zone has been investigated in $99.99 \%$ purity $\mathrm{Al}$ and $\mathrm{Al}-0.2 \% \mathrm{Cu}$ alloy ingots in which columnar grains grow in a cellular or cellular dendritic manner. Experiments on the conventional ingots and bottom chilled, unidirectionally solidified ingots show that there is a critical pouring temperature for the formation of equiaxed zone, above which no equiaxed zone forms. In the absence of pouring turbulence, however, no equiaxed zone forms even though the ingot is quenched from the temperature below the critical one. These results indicate that the pouring turbulence is an essential element in the formation of the equiaxed zone. It is also found that the chill grains in the very surface layer of the ingots have dendritic morphology.

So it is concluded that the equiaxed zone in pure $\mathrm{Al}$ and $\mathrm{Al}-0.2 \% \mathrm{Cu}$ alloy ingots is caused by the multiplication of dendritic chill crystals induced by pouring turbulence.

(Received April 24, 1970)

\section{I. 緒言}

低い注入温度、すなわち小さい過熱で注入した鋳塊に は, 非常に微細な結晶䊰から成る㳂範闻の等軸晶带が生成 することが観察されている(1)(2)。そしてその生成機構とし ては “free" chill crystal mechanism(3) が妥当であるとさ れている.しかしこれについては, 水溶液の低温注入過程 の観察(1)と2〜3の実験が苏るだけで，十分な検討がなさ れていないように思わ机る。

ぬた $\mathrm{Al}$ 鋳塊のTiによる結晶粒微細化が注入温度の影 響を強くうける(1)ことからその機構を検討(5)するうえでる この種の等軸晶の生成は重要であると考えられる.

そこで先ず本報告では，純 $\mathrm{Al}$ 捛よび $\mathrm{Al}-0.2 \% \mathrm{Cu}$ 鋳塊

A

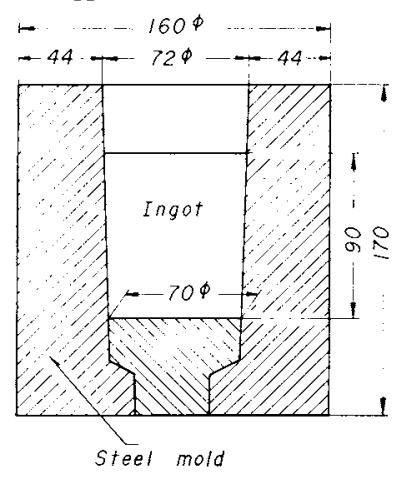

B

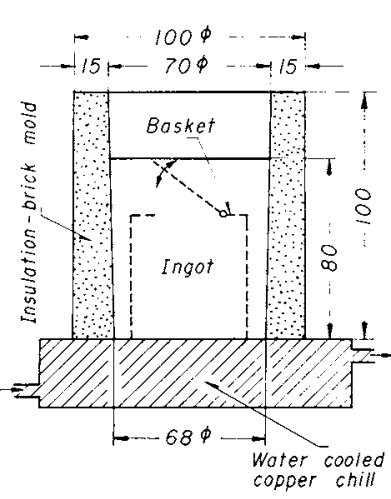

に㢷ける微細な等軸唱の起源について，现在提案されてい る等軸晶の生成機構によって検討した。

\section{II. 実 験 方 法}

供試材は $99.99 \% \mathrm{~A} 1$ 扎よび $\mathrm{A} 1-50 \% \mathrm{Cu}$ 舟合金で成分調 整を行なった $\mathrm{A} 1-0.2 \% \mathrm{Cu}$ を用いた。溶解はエレマ㭁でア ルミナるつぼ内で行なった，一溶解 $3.5 \mathrm{~kg}$ とし浴讨落ち 後ただちに低温用フラックスで脱ガスし，さらに $850^{\circ} \mathrm{C}$ に 昇温後高温用フラックスで鹃ガスした。

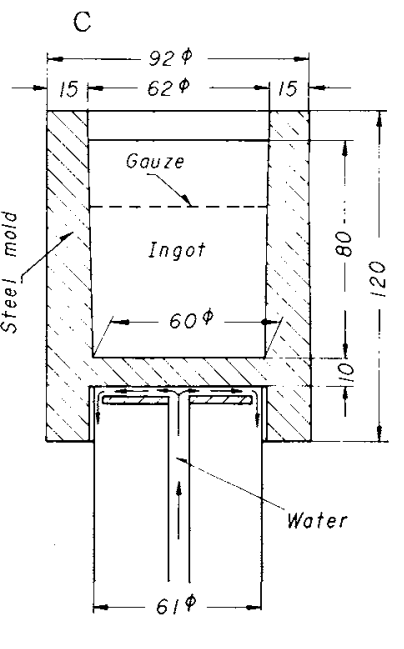

Fig.1 Schematic representation of molds A, B and C

** 株式会社神戸製鋼所中央研究所 (Central Research Lacoratory, Kobe Steel, Ltd., Kobe)

* 1969 年 10 月本会広自大会に発表

(1) K.A. Jackson, J.D.Hunt, D. R. Uhlmann and T. P.Seward, III : Trans. Met. Soc.AIME, 236(1966), 149.
(2) D.R.Uhlmann, T.P.Seward, III and B.Chalmers : Trans. Met.Soc. AIME, $236(1966), 527$.

(3) B.Chalmers : J.Aust. Inst. Met., 8 (1963) , 255.

(4) D.Eborall : J.Inst. Metals, 76 (1949) , 295.

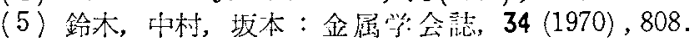


鋳型は Fig.1 に示す 3 種類のものを用いたが，鋳塊上 表面デンドライト層からの “showering” 飞起因する等軸

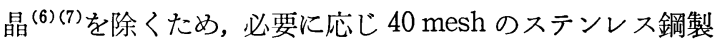
の網を鋳型に插入した。

注入温度の影響をみるためには, Fig.1 の炭素鋼製の鋳 型 $\mathrm{A}$ 用い，内面に黒鉛銤型を施し，注入時の鋳型温度を $150^{\circ} \mathrm{C}$ とした.

thermal convection を阻止するためには, Fig.1 の鋳型 Bを用い，下方より一方向凝固を行なわせた。この鋳型は イソライトれんがの側壁と，水冷銅定盤から成るが，側壁 からの凝固括よび“showering” の影響を防ぐためステンレ ス鋼製の網でつくった注入用ドアのついたかごを挿入し， かごの中の組織について検討した.

さらに，注入による溶湯の流動がない状態で凝固させる ためには, $850^{\circ} \mathrm{C}$ に加熱した Fig.1 のステンレス鋼製の鋳 型Cに $850^{\circ} \mathrm{C}$ の溶湯を注入し, 所定の温度まで放冷後, 底 部より水冷し，一方向凝固を行なわせた.

また，注入時にはげしい turbulenceを与党たり，柱状晶 の成長界面を洗うような流動を与兄るためには Fig.1 の鋳
型 $\mathrm{A}$ をーンテーブルにとりつけ，必要な時期に $100 \mathrm{rpm}$ の回転を与えた。

\section{III. 実 験 結 果}

\section{1. 注入温度の影響}

$99.99 \% \mathrm{~A} 1$ 抢よび $\mathrm{A} 1-0.2 \% \mathrm{Cu}$ 鋳塊のマク口組織に拉 よぼす注入温度の影響をPhoto.1, 2 亿示す。いずれの場 合も注入温度が高いとさは，全面柱状晶であるが, $99.99 \%$ $\mathrm{Al}$ では $665^{\circ} \mathrm{C}, \mathrm{Al}-0.2 \% \mathrm{Cu}$ では $670^{\circ} \mathrm{C}$ の注入ではじめて 等軸晶帯が観察される。 また全面柱状晶の場合は, 注入温 度が低いほど柱状粒の幅がせまくなっている．Photo.3に 等軸晶帯のミクロ組織を示す。いずれる球状の部分がみら れ, 球状粒子が密でないところは, これを頭としセル状ま たはセルラーデンドライト状の尾をむつ comet 型(6) の等軸 晶となっている。

このような低い注入温度のときみられる等軸䊀が, “showering”によるものかどうかを確めるために，金網を 扥入した鋳型で同様な実験を行なった。結果はPhoto.4 に
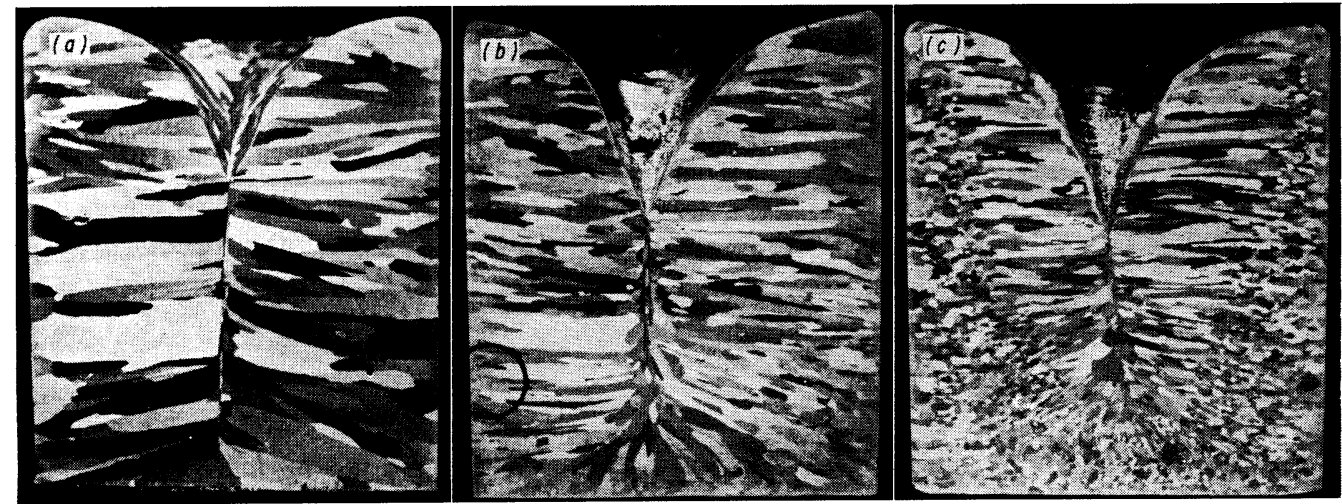

Photo.1 Macrostructures of $99.99 \% \mathrm{Al}$ ingots solidified in the mold A.Poured at (a) $720^{\circ} \mathrm{C}$, (b) $680^{\circ} \mathrm{C}$ and (c) $665^{\circ} \mathrm{C} \quad(\times 1 \times 3 / 5)$

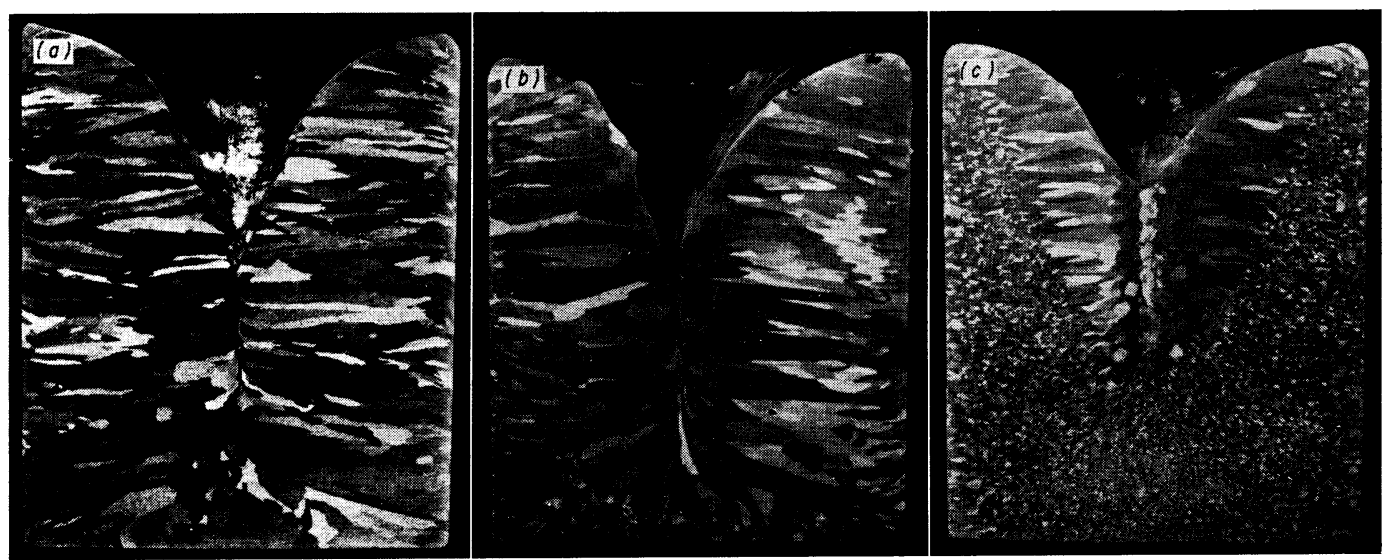

Photo. 2 Macrostructures of $\mathrm{Al}-0.2 \% \mathrm{Cu}$ alloy ingots solidified in the mold A.Poured at (a) $720^{\circ} \mathrm{C}$, (b) $680^{\circ} \mathrm{C}$ and (c) $670^{\circ} \mathrm{C}(\times 1 \times 3 / 5)$

(6) R.T.Southin : Trans. Met.Soc.AIME, 239 (1967), 220 .
（7）鈴木, 中村, 坂本 : 金属学会誌, 33 (1969), 834. 


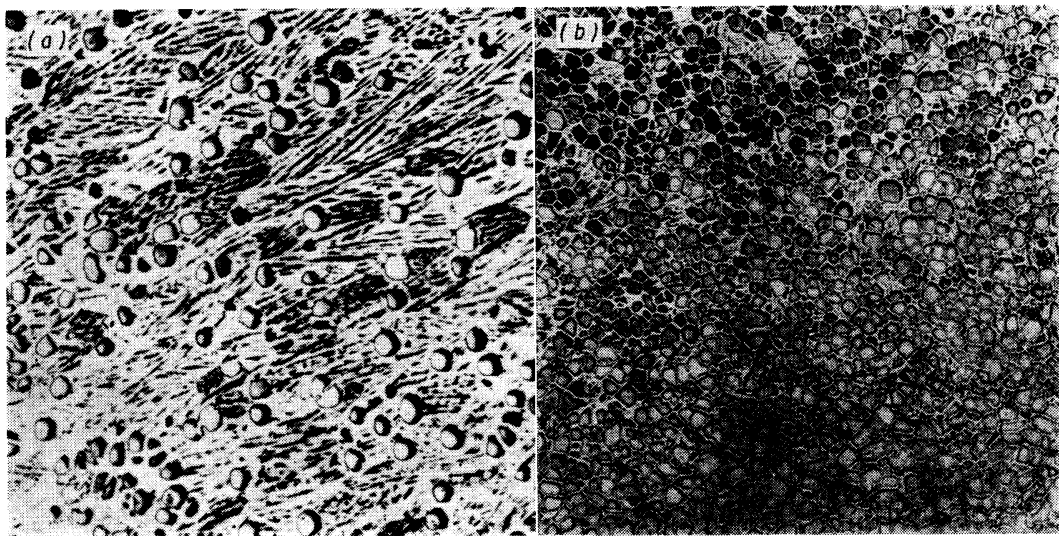

Photo.3 Photomicrographs of equiaxed grains: (a) corresponding to Photo.1 (c); and (b) to Photo. $2(\mathrm{c})$, respectively $(\times 10 \times 2 / 3)$
以上の実験とは反対に，溶湯 の流動を増大させるために, 回 転中の鋳型に注入し，凝固初期 の溶湯の流動を大きくして注入 温度の影響を調べた. $100 \mathrm{rpm}$ で回転している鋳型に注入した が,この場合も Photo.1, 2 と同 じ注入温度ではじめて等軸晶が 生成した (Photo.7に Al-0.2\% $\mathrm{Cu}$ について示した).

また $99.99 \% \mathrm{Al}$ および $\mathrm{Al}$ $0.2 \% \mathrm{Cu}$ 鋳塊の柱状晶のサブ組 織はPhoto. 8 に示すように側 枝のないセル状またはセルラー

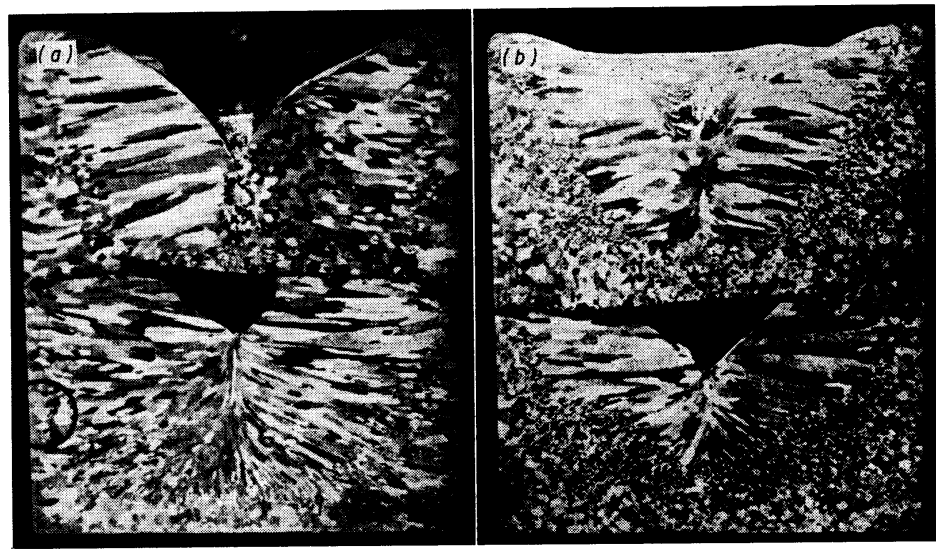

Photo.4 Macrostructures of ingots solidified with a gauze barrier inserted in the mold $\mathrm{A}$ : (a) $99.99 \% \mathrm{Al}$, poured at 665 ${ }^{\circ} \mathrm{C}$; (b) $\mathrm{Al}-0.2 \% \mathrm{Cu}$, at $670^{\circ} \mathrm{C}(\times 1 \times 3 / 5)$

亦すよ5に，前と同じく $99.99 \% \mathrm{Al}$ では $665^{\circ} \mathrm{C}, \mathrm{Al}-0.2 \%$ $\mathrm{Cu}$ では $670^{\circ} \mathrm{C}$ の注入温度で等軸粒が生成し, 金網の下に む同様の微細な等軸晶が認められた.

\section{2. 溶湯の流動の影響}

等軸粒の起源として, 柱状デンドライトの側枝の melt off が考えられ，そのためには対流が重要な役割りを果す ことが示されている(1). したがって柱状晶の成長界面に対 して作用する対流を阻止するため, Fig.1 の鋳型Bを用い て下方より一方向凝固を行なわせた. 結果は Photo.5 に示 すように，この場合も， $99.99 \% \mathrm{Al}$ では $665^{\circ} \mathrm{C}, \mathrm{Al}-0.2 \%$ $\mathrm{Cu}$ では $670^{\circ} \mathrm{C} て ゙$ 注入したとき等軸晶が観察され，これよ り高い注入温度では全面柱状晶であった。

つぎに注入流の影響をなくすために, Fig.1 の鋳型Cを 用いて, いろいろな温度から底部を水冷して一方向凝固を 行なわせた. Photo.6 に鋳塊のマクロ組織を示すが, 水冷 開始温度が前述の実験では等軸晶の生成する温度になって も, 等軸晶は生成せず比較的幅の広い柱状晶から成ってい る.この結果は, 等軸晶の生成には注入流が不可欠である ことを示している.
デンドライト状である。したがって溶湯の 流動による柱状晶の melt off またはbreak off は考えにくいが，この点を確めるため に注入 $10 \mathrm{sec}$ 後から回転停止を $10 \mathrm{sec} こ ゙$ とに繰りかえし，成長している柱状晶界面 に溶湯の流動を与えた. 結果はPhoto.9 に 示すように, マクロ組織では等軸晶は認め られなかった。これらの鋳塊の水平断面を 同時に示したが，鋳型の回転－停止による 溶湯の流動方向の変化に対応して，柱状晶 の成長方向がジグザグになっている(8) (10). Photo.10 はそれらのミクロ写真で, 99.99\% $\mathrm{Al}$ の場合はそのサブ組織は変化し ないが， $\mathrm{A} 1-0.2 \% \mathrm{Cu}$ では柱状晶の成長方 向が変化した直後からわずかの間, 明らかに側枝の生成が みられ，凝固層と末凝固溶湯の相対流動が少なくなるにつ れて，また側枝のない単純な組織になっている.ささらに側 枝の認められたところで新しい comet 型の等軸晶の生成 が認められた (Photo.10(c) 矢印).

以上の結果は柱状晶が側枝のないセル状の $99.99 \% \mathrm{~A} 1$ で は溶湯の流動によっても新しい結晶は生成しないが， A1$0.2 \% \mathrm{Cu}$ では回転により柱状晶が側枝のあるデンドライ ト状になるため, melt off またはbreak off により新しい 結晶が生成したことを示している.

したがって柱状晶が側枝のない場合には“multiplication’ を括こさないことが明らかである。

\section{IV. 考察}

以上の実験結果は, 微細な等軸晶の生成には, 注入温度 が低く, かつ注入流などの溶湯の流動が凝固初期に必要で

(8) W. Roth and M. Schippen : Z.Metallk., 47 (1956), 78.

(9) F.C.Langenberg, G. Pestel and C. R. Honeycutt : Trans. Met.Soc. AIME, 221 (1961), 993.

(10) 阿部, 戸叶：金属学会誌, $33(1969), 970$. 


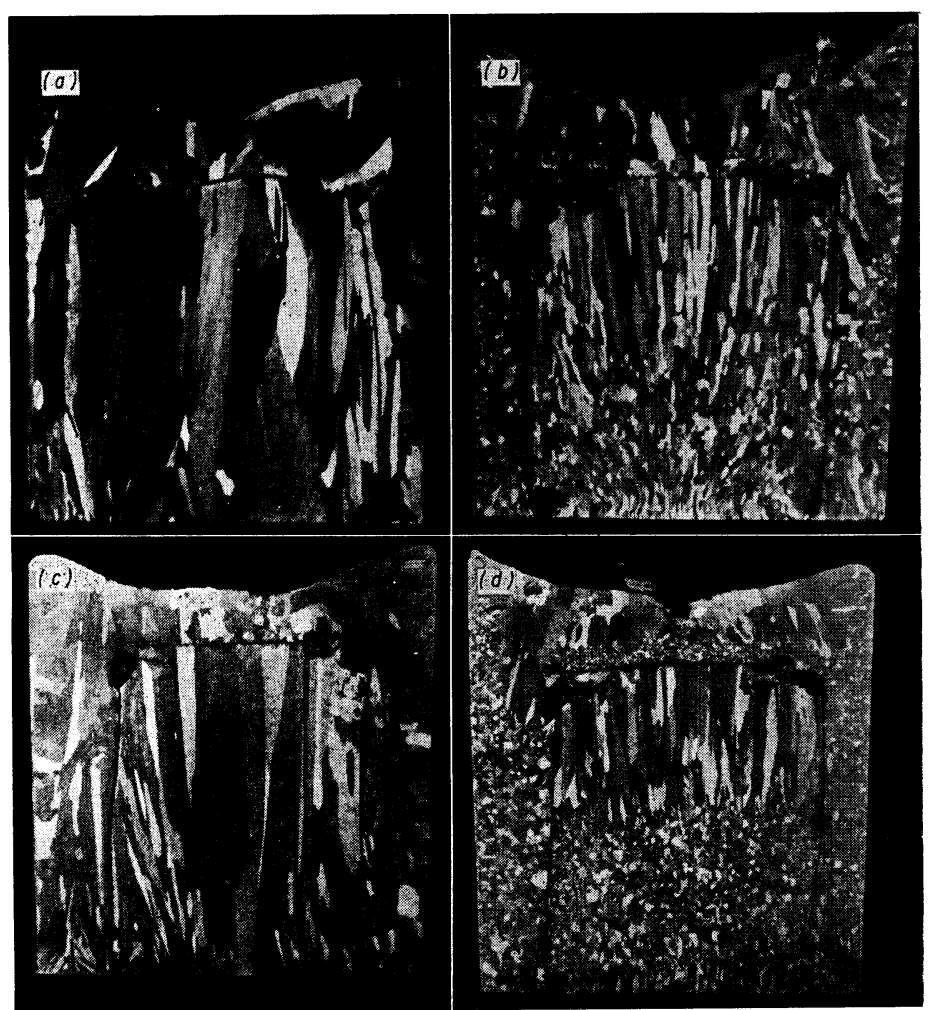

験でみられた等軸晶の生成機構としていずれ が最も妥当であるかを検討してみよう。

柱状晶のサブ組織は組成的過冷の大きさに よってセル状からセルラーデンドライト状に 変化し ${ }^{(12)(13)}$ ，さらに組成的過冷が大きくな ってはじめて界面前方の溶湯中で等軸晶の核

Photo.5 Macrostructures of ingots solidified unidirectionally in the mold B : $99.99 \% \mathrm{Al}$, poured at (a) $720^{\circ} \mathrm{C}$ and (b) $665^{\circ} \mathrm{C} ; \mathrm{Al}-0.2 \% \mathrm{Cu}$, at (c) $720^{\circ} \mathrm{C}$ and (b) $670^{\circ} \mathrm{C}(\times 1 \times 3 / 5)$

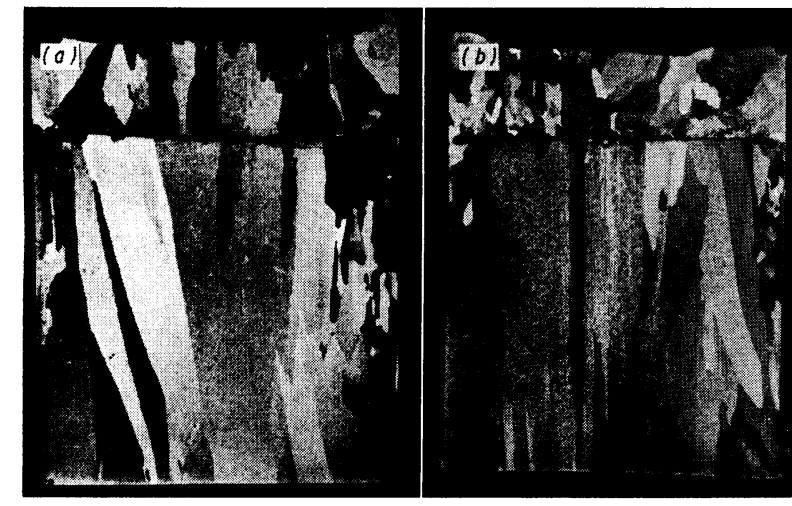

Photo.6 Macrostructures of ingots solidified unidirectionally in the mold $\mathrm{C}:$ : (a) $99.99 \% \mathrm{Al}$, quenched from $665^{\circ} \mathrm{C}$; (b) $\mathrm{Al}-0.2 \% \mathrm{Cu}$, from $670^{\circ} \mathrm{C}(\times 1 \times 3 / 5)$

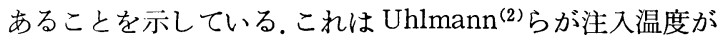
低い場合，自然対流を小さくしても等軸晶が生成すること を観察し，Spittleら ${ }^{(11)}$ がこれは注入流の影響によると指摘 しているのに一致する．そしてこの説明には “free” chill crystal mechanism ${ }^{(3)}$ が最も妥当であるとされているが, 等軸晶の生成に対してこのほかに三つの提案があり，いず れも実験的には抗こりらることが示されているので，本実

(11) J. A. Spittle, G. W. Dellamore and R. W. Smith : The Solidification of Metals, ISI, Pub.110, (1968), 318.

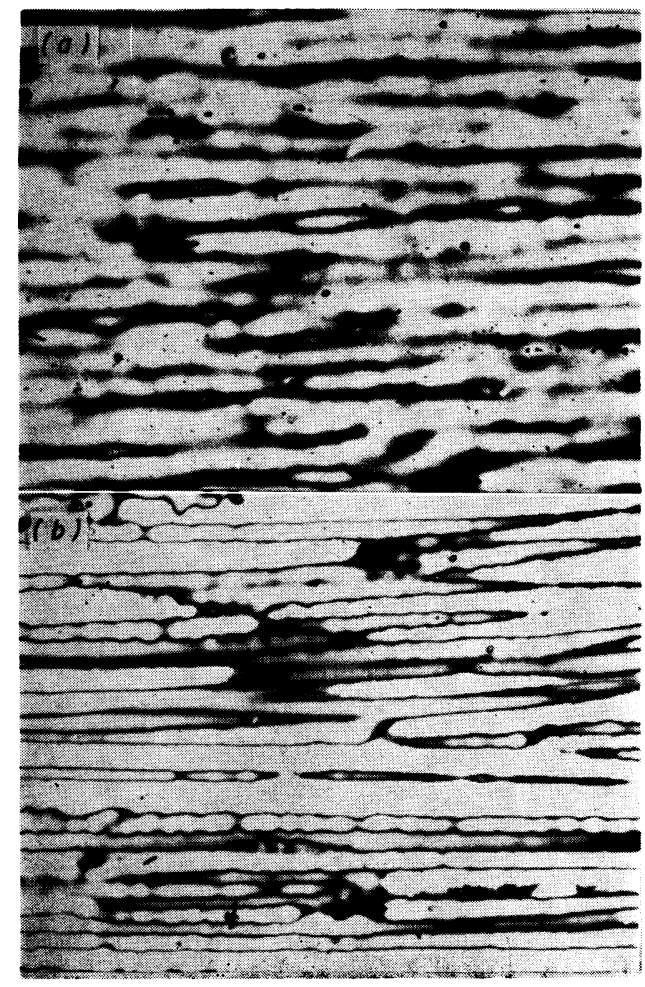

Photo.8 Photomicrographs of columnar grains : (a) $99.99 \% \mathrm{Al}$, corresponding to Photo. 1 (a) ; (b) $\mathrm{Al}-0.2 \% \mathrm{Cu}$, to Photo.2 (a) respectively $(\times 50)$ 


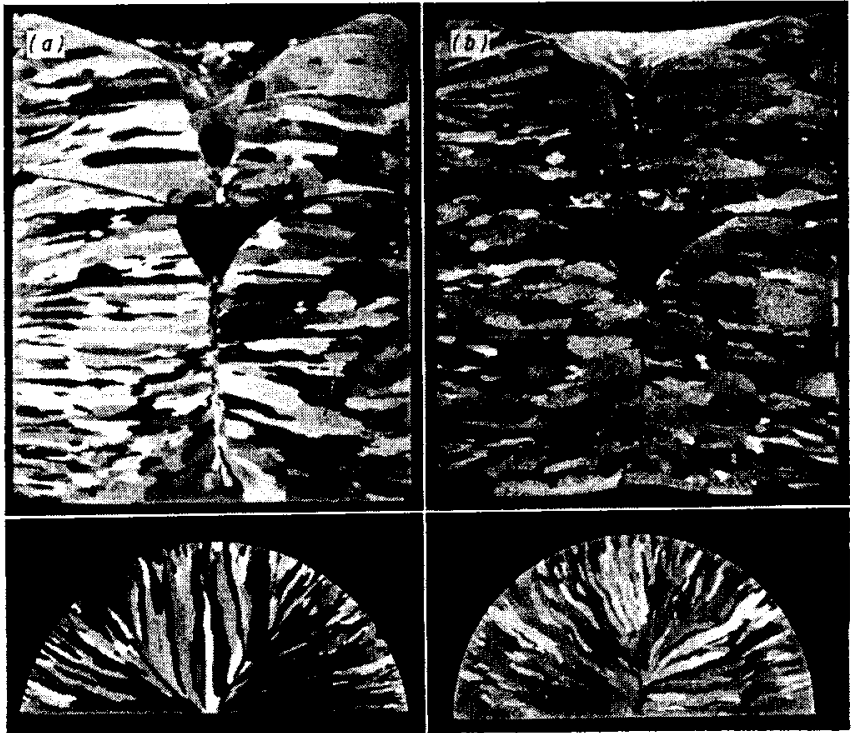

Photo.9 Macrostructures of ingots poured at $720^{\circ} \mathrm{C}$. Rotation started $10 \mathrm{sec}$ after pouring and stopped for $10 \mathrm{sec}$ every $10 \mathrm{sec}$ (a) $99.99 \% \mathrm{Al}$, (b) $\mathrm{Al}-0.2 \% \mathrm{Cu}(\times 1 \times 3 / 5)$

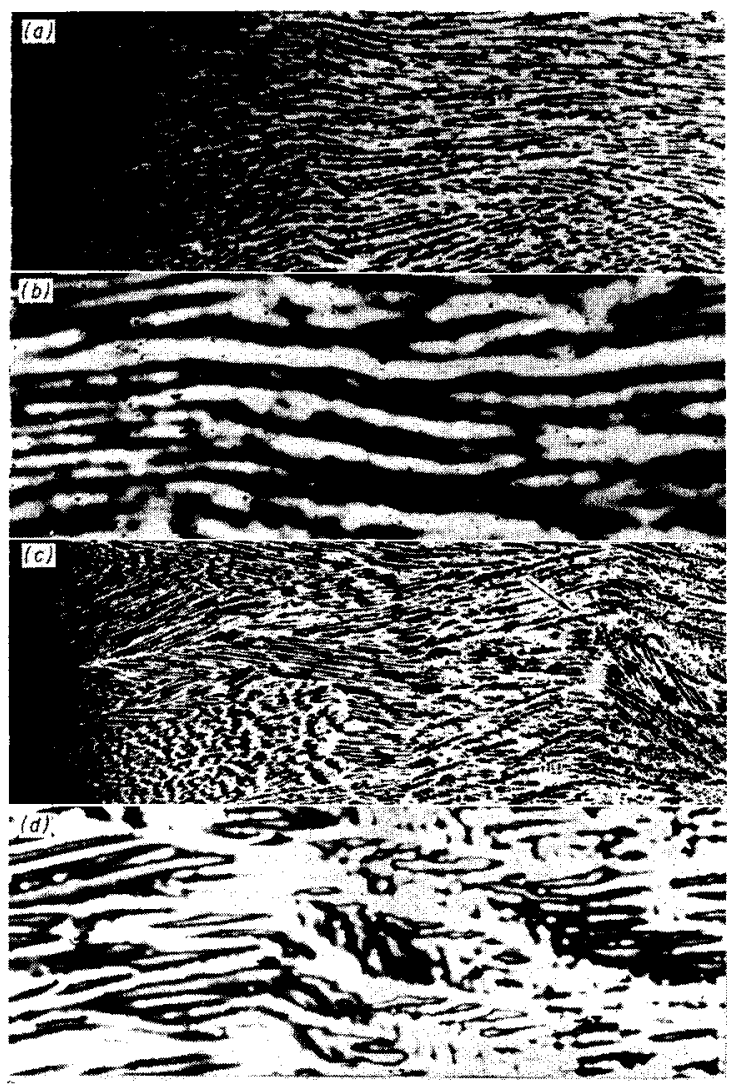

Photo.10 Photomicrographs of zig'zagged columnar grains : (a), (b) corresponding to Photo.9 (a) ; (c), (d) to Photo.9(b), respectively (a), (c) $(\times 10 \times 1 / 2) ;($ b) , (d) $(\times 50 \times 1 / 2)$

(12) W. A. Rutter and B. Chalmers : Can. J. Phys., 31 (1953) , 15.
生成が物こるものとされている(14).しかし本実験 の場合 $99.99 \% \mathrm{Al}$ と $\mathrm{A} 1-0.2 \% \mathrm{Cu}$ 錆塊の柱状晶 のサブ組織はセル状またはセルラーデンドライト 状であるから界面拉方の溶清中の組成的過冷の大 きさが核生成をおこすほど大きくなっているとは 考光ら机な。

つぎに柱状晶のデンドライトアームの melt off(1)または break offによる等軸晶の生成も，柱 状晶のサブ組織から遊墔されるべき側枝がなく， 側枝のないときにはこのょうな“multiplication” のおこらないことが回轻㠜国实焦によって確認さ れたので,この機構もこのさい働いていないるの と思われる。

また鋳塊上表面デンドライト風からの “showering”(6)西鋳塊に塖入した金網の下方にも 等㑲晶が観察されているので，本実験ではこの機 構も考えなくてよい.

巳て, "free" chill crystal mechanism

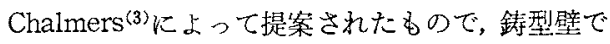
過冷された溶湯中で “copious”な核生成がおこり，これが 鋳垉内部に運ばれて成長し等軸鼠になるとするるので, Walker(15) は catalyticaly にきれいな合金です等糔嵌が生 成することは，この機構でうまく㳳明汁来るとしている。 そして Biloni and Chalmers ${ }^{(16)}$ は銑型表偭で predendritic な凝固が抗こりこれが等粙昆の起源になることを示咬して いる.

最近 Bower and Flemings ${ }^{(17)}$ は “free” chill crystal

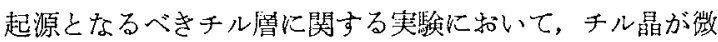
細化するのは copious な核生成よりは浚湯の流動があるた めの “multiplication”によるとし, Biloni and Morando(18) は“Copious”な核生成と溶湯の流動による“multiplication” の二つが考えられることを示している。

本実験の場合，以上の結果のみでは等軸粒がそれぞれ別 個に核生成したものか, “multiplication”によるものかは 断定できないが，注入流が必要なことから“multiplication”の可能性が大きいと考えられる。

しかし “multiplication”を括こすためにはデンドライト が必要であると考方られるので，99.99\% Al の紫合であ凝 固の初期にデンドライトが生成しなければならないと思か れる。

(13) W. A. Tiller and J.W. Rutter : Can. J. Phys., 34 (1956), 96.

(14) W.C.Winegard and B.Chalmers : Trans. ASM, 46 (1954), 1214.

(15) J. L. Walker : Trans, 6 th Vacuum, Met. Conf., (1963), 33 .

(16) H.Biloni and B.Chalmers : Trans. Met.Soc. AIME, $233(1965), 373$.

(17) T.F.Bower and M. C. Flemings : Trans. Met. Soc. AIME, $239(1967), 216$.

(18) H.Biloni and R.Morando : Trans. Met. Soc. AlME, $242(1968), 1121$. 
そこで鋳塊の最外層領域のミクロ組織を調査した。 Photo.11(a), (b) は等軸晶が観察された $99.99 \% \mathrm{Al}$ 鋳塊 Photo.4 (a)の丸印内のミクロ組織を示す. 球状の部分と矢 印で示す分裂途中で凝固が終了したと思われる等軸デンド ライトが観察される。またこの断面では鋳塊表面層でデン ドライトが存在するかどらかはわかりにくいので, 鋳塊表 面に対して斜めの断面で組織を観察したところ Photo.11 (b) に示すようにデンドライトが生成していることが観察 された. Photo.12 は回転中の鋳型に低温度で注入した Photo.7 の鋳塊でみられたもので, チル層から遊離したデ ンドライトが早い時期に柱状晶にトラップされて球状にな らなかったものと考えられる。

したがって低温注入のさいみられた微細な等軸晶の起源 は，柱状晶がセル状である $99.99 \% \mathrm{Al}$ のよ5な高純度な ものでも注入後きわめて早い時期に比較的大きい過冷のも

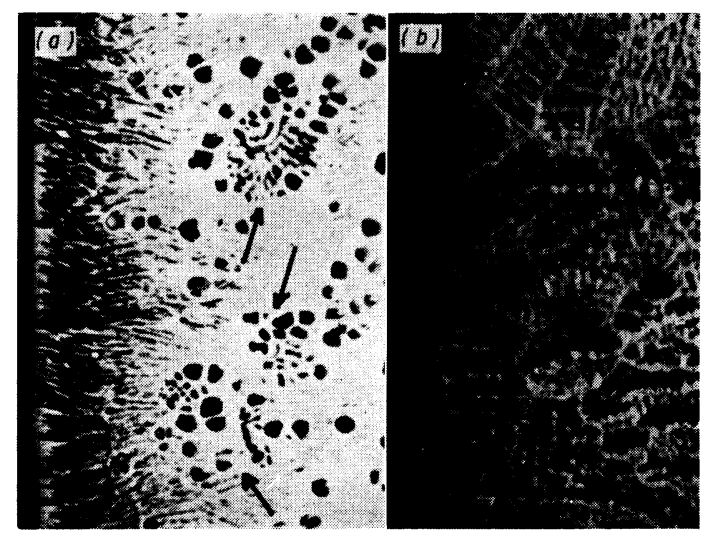

Photo.11 Photomicrographs of chill crystals (left); (a) perpendicular section and (b) inclined section to the cyrindrical surface. Photographed position is indicated in Photo. 4 (a)
(a) $(\times 10 \times 2 / 3)$,
(b) $(\times 20 \times 2 / 3)$

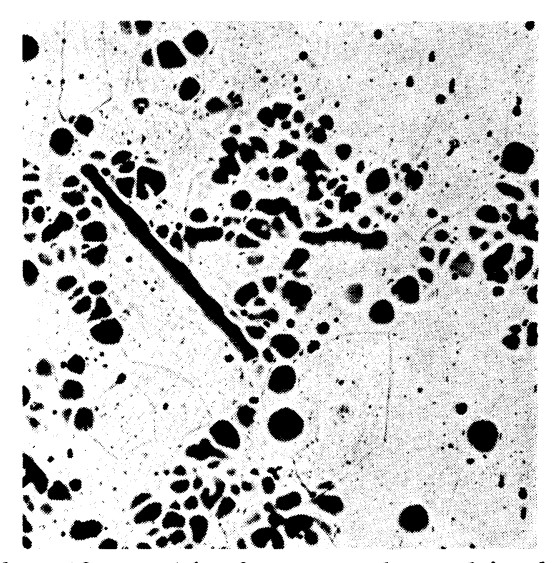

Photo.12 Dendrite fragments observed in the region near the chill zone : corresponding to Photo.7 $(\times 20 \times 2 / 3)$
とで, デンドライト状のチル晶が生成し, 注入流の影響に よって分裂して鋳型内部に運ばれたことによると結論出来 る.

しかしこのデンドライトの “multiplication”が melt off(1)(19) によるものか break off(19) (20) によるものなのかは な特検討が必要である。

いっぽう等軸晶が生成しなかった高温注入の $99.99 \% \mathrm{~A} 1$ 鋳塊 Photo.1(b) の丸印の位置でも Photo.13に示すよ5 に, 鋳塊の最外層にデンドライト状のチル晶が観察される が, この場合等軸晶が生成しなかったのは, 溶湯の過熱が 大きいため分裂して運ばれたデンドライトの断片が全部再 溶解してしまったのか, 注入温度が高いため注入流が静ま ってから最外層のデンドライトが生成したため“multiplication”をおこさなかったのかのどちらかであろう.

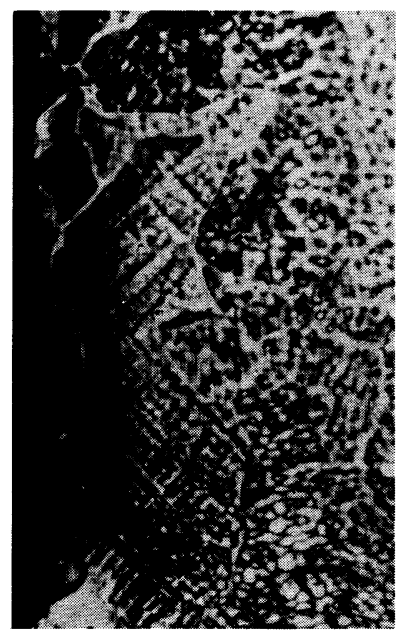

Photo.13 Photomicrograph of chill zone (left) ; inclined section to the cyrindrical surface. Photographed position is indicated in Photo. 1 (b) $(\times 20 \times 4 / 5)$

\section{V. 結 論}

$99.99 \% \mathrm{Al}$ および $\mathrm{A} 1-0.2 \% \mathrm{Cu}$ 鋳塊に括いて, 注入温度 が比較的低いときに生成する等軸晶の起源について次の点 を明らかにした。

（1）用いた試料の柱状晶はセル拉よび側枝のないセルラ ーデンドライトであるが, 鋳瑰の最外層には, デンドライ ト状のチル晶が生成する。

（2）注入流のような比較的強い溶湯の流動があると，こ のデンドライト状のチル晶が “multiplication”をおこし等 軸晶の起源となる.

(19) F.A. Grossley, R. D. Fisher and A. G. Metealfe : Trans. Met.Soc. AIME, 221 (1961), 419.

(20) S. O'Hara and W.A.Tiller : Trans. Met.Soc. AIME, 239 (1967) , 497. 